\title{
Phylogenetic relationships within the Scylla (Portunidae) assessed by the mitochondrial DNA sequence
}

\author{
HURUL ADILA-AIDA MOHAMAD ROSLY, SITI AZIZAH MOHD NOR, DARLINA MD. NAIM" \\ School of Biological Sciences, Universiti Sains Malaysia, 11800 Penang, Malaysia. Tel./Fax: +60-04 653 4056, `email: darlinamdn@usm.my.
}

Manuscript received: 27 August 2017. Revision accepted: 30 October 2017.

\begin{abstract}
Rosly HAAM, Mohd Nor SA, Md. Naim D. 2017. Phylogenetic relationships within the Scylla (Portunidae) assessed by the mitochondrial DNA sequence. Biodiversitas 18: 1696-1704. This study was centered around the phylogenetic of mud crab genus Scylla collected across Malaysia based on a 542 base pairs (bp) section of the mitochondrial cytochrome c oxidase I (COI) from 201 individuals. Sampling locations were nine areas including one location from Borneo (Sabah and Sarawak). The Maximum Parsimony (MP) and Neighbor-Joining (NJ) methods was conducted for phylogenetic analysis and performed in MEGA ver. 5.05. We found that S. olivacea is the plenteous species collected with 111 individuals, followed by S. tranquebarica with 61 individuals. Scylla paramamosain is barely found throughout our sampling locations with only 29 individuals caught in this study. Regrettably, no wild samples of $S$. serrata was found during our sampling occasions, accordingly life specimens were purchased from restaurants to complete the analysis. Both MP and NJ phylogenetic trees shows a monophyletic relationships among all four species within genus Scylla included in this study. This was also supported by the genetic distance analysis based on Tamura-Nei which indicates that there is high interspecific and low intraspecific genetic distances among and within species of Scylla included in the analysis. This investigation divulged a solid proof that supports the occurrence of three species of Scylla with the nonappearance of S. serrata in Malaysian waters. This current investigations could serve as a guidance for promoting further assessment on aquaculture and conservation management for the species.
\end{abstract}

Keywords: Scylla, phylogenetics, COI, mud crab, conservation

\section{INTRODUCTION}

Malaysia is identified as one of the world's megadiversity center and a biodiversity hotspot, in which it has the total coastline length of $4675 \mathrm{~km}$ while the mangroves area occupies $5053.45 \mathrm{~km}^{2}$ (Wong 2004). This large expanse of water space and various aquatic habitats (e.g. rivers, peat swamps, reservoirs, former mining pools and paddy fields) provide good opportunity for colonization of a large numbers of endemic and unique marine organisms (Abdullah et al. 2017; Imtiaz et al. 2017). Mud crabs of the genus Scylla (Portunidae) is also known as swimming crabs due to the broad paddles of the flattened fifth pair of legs that was used to dig into the mud (Ng et al. 2008). They are native to the Indo-West Pacific Ocean such as South Africa, Red Sea, Australia, Philippines, Pacific Islands, Taiwan and Japan (Fratini et al. 2010). In Malaysia, mud crab or locally known as ketam nipah or ketam bakau inhabits mangrove forests and river mouths in estuarine environments, where they can be found along the west and east coast of Peninsular Malaysia, Sabah and Sarawak.

Mud crabs has an excessive market demand where the price may fetch around Malaysia Ringgit (MYR) 40 - 60 per kilogram in a market, especially females with mature ovaries. As a consequent, the species belong to this genus is the most important crab for commercial culture and export markets (Keenan 2004) particularly in the tropics (Bell and Gervis 1999; Williams and Primavera 2001). To illustrate, the story of mud crab aquaculture has been started in China since centuries ago (Yalin and Qingsheng
1994) and Ikhwanuddin and Oakley (1999) reported that it has been started in other Asian region since more than three decades ago. Due to its high commercial value, mud crab is extensively cultured and captured (Keenan 2004). Further exacerbating the situation is that the broodstocks are almost entirely caught from the ocean (Xu et al. 2009). Additionally, juveniles are caught for seeding in ponds or enclosures while adults and subadults were used for fattening and soft-shell crab production (Le Vay 2001; Sara et al. 2002; Sara 2010). As a result of increased fishing effort over time and unregulated nature of fishery, there are indications that crab populations have decreased significantly (see e.g. Francis and Bryceson 2001; Mahika et al. 2005; David 2009; Xu et al. 2009). In spite of continuous harvest pressure, this species is managed in only a few parts of their range (e.g. northern Australia, Pillans et al. 2005), and, as a consequence, they become smaller and harder to catch in many places especially in developing countries (Gopurenko et al. 2002; Ewel 2008).

Initially, only one species from genus Scylla has been revealed namely Scylla serrata (Forskål 1775), until the research conducted by Estampador (1949) has made it clear that there are more than just one species occurred within the genus. Consequently, to reveal the puzzles about the taxonomic nomenclature of Scylla, several research and reviews were made (see Joel and Raj 1980; Fuseya and Watanabe 1996; Overton et al. 1997), until genetic and molecular research (allozyme electrophoresis, mitochondrial genes and nuclear genes) have come up to provide insight into the taxonomy of the genus (Keenan et 
al. 1995; Keenan et al. 1996; Fuseya and Watanabe 1996; Keenan et al. 1998; Keenan 1999; Imai et al. 2004). Accordingly, four distinct species have been successfully revealed (Keenan et al. 1998; Keenan 1999; Imai et al. 2004).

In spite of its commercial interest and the declining status of mud crab genus Scylla, globally, knowledge of the genetic and demographic structures of wild populations is limited to a few studies (Gopurenko et al. 2002; see e.g. Keenan et al. 1998; Gopurenko et al. 1999; Gopurenko and Hughes 2002; Xu et al. 2009; for details study). Furthermore, despite the fact that it is an important food resources, only a few documented research on the phylogenetic and population of this species has been reported in Malaysia. In this context, identifying the genetic characteristics of a population and the rate of migration and/or gene flow can give insights into some of the key processes and factors influencing the substantiality of populations (Gauffre et al. 2008). It is also an important prerequisite, which may be crucial for effective conservation (i.e. conservation genetics) of the species concerned. The genetic information obtained would help in delineating proper sustainable management strategies and predicting the effects of proposed management alternatives on the viability of a species.

Additionally, genetic information is crucial in characterizing a species and for monitoring a potential changes in the genetic makeup and adaptive values as a result of interaction between wild and cultured populations, translocation or environmental changes (Jørstad et al. 2004; Utter 2004; Perrier et al. 2013) of this economically important species. The blending of cultured mud crabs with unadulterated wild stock found in open water bodies may accrue in unfit mud crabs contrasted with the local wild stock. Genetic data would, likewise, be helpful in the determination of ideal stocks for an efficient rearing projects and restocking. In the former, populations with high genetic diversity are chosen as broodstocks, while in the later, populations with high intraspecific genetic distance are required as contributor and beneficiary populations to guarantee the compatibility of gene pools of both populations (Lawlor and Hutchings 2004; Utter 2004). Furthermore, as genetic materials is acquired, it manifests heredity and is dependable for studying phylogenetic relationships.

In this study, phylogenetic analysis of mud crab genus Scylla collected across Malaysia was conducted by utilizing the mitochondrial DNA cytochrome oxidase subunit I (COI) sequencing. Due to quick changes of animal mtDNA base sequences, mtDNA COI is an effective method for evaluating hereditary connections of individuals or populations within and between species and furthermore to identify and measuring the phylogeny among various species.

\section{MATERIALS AND METHODS}

\section{Sample collection}

The sampling activity was performed during the years 2010 to 2012 from nine mangrove areas in Malaysia. A total of nine locations were chosen for sampling. Several field trips were conducted across Peninsular Malaysia before the selection of suitable sampling locations. Consequently, nine suitable locations were selected and these include two locations from the east coast of Peninsular Malaysia namely Kelantan and Terengganu, four locations from the west coast of Peninsular Malaysia namely Langkawi, Kedah, Penang, Perlis and Perak, and only one location from Johor (south of Peninsular Malaysia). We also managed to sample individuals from a single population from Sarawak and Sandakan, Sabah, both located within the Borneo region. Justification of choosing these sampling locations is that they encompass the distributional range of mud crab genus Scylla within Malaysian waters. Crab pots with fish as bait were used to trap and catch the crab. Approximately seven crab pots were placed at identified mangrove areas in all sampling locations. The trap were spaced at precisely 100 meter apart from each other and were monitored for three successive days, 24 hours per day. Fortunately, our sampling activities were also facilitated by personnel from the Fisheries Research Institute (FRI) and the Department of Fisheries Malaysia (DoF). All samples caught were morphologically identified and classified on the basis of morphology and body coloration.

Approximately $2 \mathrm{~cm}$ segment of muscle tissues from a right single claw of each crab was clipped and fully dipped in a labelled $2 \mathrm{ml}$ eppendorf tubes containing 95\% alcohol for DNA extraction. These reference specimens were then transported to Lab 308, Universiti Sains Malaysia for molecular analysis. The voucher specimens were deposited at the Centre of Marine and Coastal studies (CEMACS) Collection Centre, Muka Head, Penang following standard preservation protocol.

Preservation of voucher specimen is a central part to record biodiversity samples through time and the most crucial step for this purpose is fixation. In this study, all voucher specimens were thoroughly cleaned with water to remove any contamination. The specimens were initially fixed in $10 \%$ formalin for a week. This solution is ideal for fixation of a marine organism in a tropical environment such as Malaysia. After a week, all samples were removed from formalin and rinsed with water to wash out excessed formalin.

\section{Polymerase chain reaction (PCR) and sequencing}

Total genomic DNA from all the specimens were extracted based on the protocols from AquaGenomic Solution Kit (BioSyntech, USA) in the presence of Proteinase $K$. A slight modification of the original protocol was made in order to get maximum yield of DNA. The quality and quantity of extracted DNA was checked by electrophoresis, which was conducted on a $1 \%$ agarose gel in Tris-Borate-EDTA (TBE) buffer solution at $100 \mathrm{~V}$, $500 \mathrm{~mA}$ for approximately one hour. The agarose gel was stained with ethidium bromide (EtBr) prior to visualization for the presence of the extracted DNA band in a gel documentation system (GENE Flash). The intensity of band indicates DNA quality. The quality and quantity of extracted DNA were also confirmed by use of 
spectrophotometer. The DNA quality having values 1.8-2.0 based on OD260/OD280 and quantity above $10 \mathrm{uL}$ suspended in $50 \mathrm{uL}$ of $\mathrm{ddH}_{2} \mathrm{O}$ were chosen for Polymerase Chain Reaction (PCR) amplifications.

The isolated DNA template was amplified using primer pair of cytochrome oxidase c subunit I (COI). Primers used for amplification were: Mtd-10 5'- T TGA TTT TTT GGT CAT CCA GAA GT - 3' (Roehrdanz 1993) and C/N 2769 5'- TT AAG TCC TAG AAA ATG TTG RGG GA - 3' (Gopurenko et al. 1999). PCR was conducted in an eppendorf Master Cycler in a total volume of $20 \mathrm{uL}$ based on the optimized conditions. The mixture consists of $10 \mathrm{x}$ PCR buffer, $2.5 \mathrm{mM}$ dNTP mixture, 5U of $i$-Taq DNA polymerase, $25 \mathrm{mM} \mathrm{MgCl}_{2}, 0.5 \mathrm{pmol}$ of each forward and reverse primer and $1.6 \mu \mathrm{l}(20 \mathrm{ng})$ of DNA from each sample. Aliquots were then transferred into each of $0.2 \mathrm{~mL}$ labelled tube with DNA individually added for each sample. The thermal regime were $35 \times\left[94^{\circ} \mathrm{C}\right.$ for $30 \mathrm{~s}, 50^{\circ} \mathrm{C}$ for $30 \mathrm{~s}, 72^{\circ} \mathrm{C}$ for $1 \mathrm{~min}, 94^{\circ} \mathrm{C}$ for $3 \mathrm{~min}$ ] and a final incubation at $72^{\circ} \mathrm{C}$ for $5 \mathrm{~min}$. All amplified PCR products were then purified by using MEGA Spin Total Fragment DNA Purification Kit (Intron Biotechnology INC. Korea), an important step to avoid excess nucleotides, salts or primers. The purified PCR product was run on a $1.5 \%$ agarose gel with $100 \mathrm{bp}$ ladder to compare the length of amplified PCR products and visualized on a GENEFLASH Syngene Bio Imaging prior to send for sequencing. Purified PCR products were stored at $4^{\circ} \mathrm{C}$ in a freezer.

The PCR products were then purified according to the protocols from PCR Purification kit (PROMEGA) and sent to First Base Laboratories Sdn Bhd ( $1^{\text {st }}$ BASE) for sequencing. Sequencing of products was done on the Applied Biosystems machine based on principles of Sanger sequencing method (dideoxy sequencing). The dideoxy nucleotides were fluorescently labelled and each nucleotide position was read based on different wavelengths.

\section{Sequence analysis}

Multiple DNA sequences were compiled, edited and aligned to generate unambiguous operational taxa units using Clustal W ver. 1.6 (Thompson et al. 1994) which is integrated in MEGA ver. 5.05 (Tamura et al. 2011). This was also includes four sequences of adult $S$. serrata based on morphological inspection (samples were obtained from a restaurant and it is believed to have originated from Sulawesi -3 sequences and Pulau Jawa -1 sequence, respectively). Another three sequences of $S$. serrata from GenBank that originated from three different countries were also included in this analysis. Sequences were then blast in BOLD (Barcode of Life Database system) and BLAST (Basic Local Alignment Search Tool) database (http://www.ncbi.nlm.nih.gov/blast) to assign each individual into its respective taxon.

\section{Phylogenetic analysis}

Intraspecific and interspecific pairwise genetic distances $\left(D_{s}\right.$; Nei 1972; Nei 1978; Kalinowski 2002) were calculated under the Tamura-Nei genetic distance (Tamura and Nei 1993) performed in MEGA ver. 5.05 software (Tamura et al. 2011) for COI gene with gaps treated as missing data. The same software was used to cluster COI haplotypes into a Maximum Parsimony (MP; Farris 1983) and Neighbour-joining (NJ) phylogeny, employing 10, 000 bootstrap replicates. To clearly present the phylogenetic tree, only 51 sequences including the four sequences of $S$. serrata obtained from restaurant were used to construct both MP and NJ trees as representatives of all sequences. Both tree reconstructions were rooted using two indigenous portunids Stoliczia chaseni (GeneBank accession number: AB290645.1) and Johora singaporensis (GeneBank accession number: AB290641.1) as an outgroup.

\section{RESULTS AND DISCUSSION}

A total of 201 samples of genus Scylla were successfully collected across the nine sampling locations across Malaysia (Figure 1).
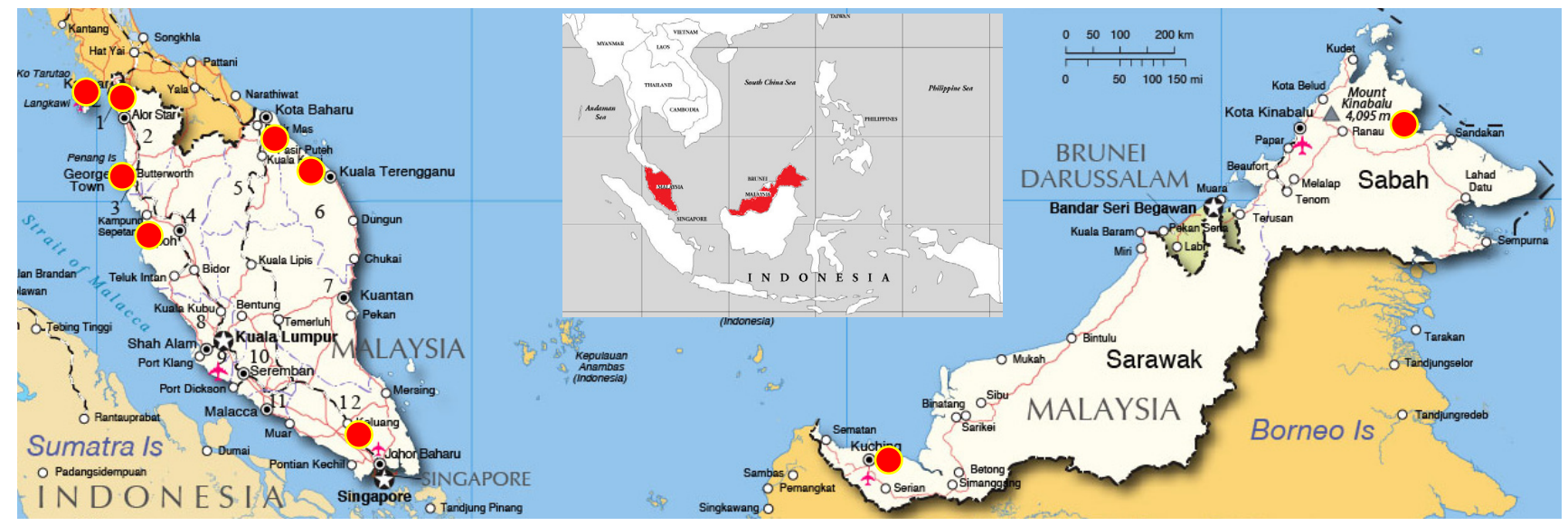

Figure 1. Location of the nine sampling sites across Malaysia 
Of these, less than 100 adult crabs were positively assigned to three species based on their morphological characters namely $S$. olivacea, $S$. tranquebarica and $S$. paramamosain. The rest of the samples failed to assign to their respective species based on their morphological characteristics because they are immature samples. Among the total samples, $S$. olivacea was the most commonly occurred species with 111 individuals collected from all sampling localities (except Johor and Sabah), followed by $S$. tranquebarica and S. paramamosain with 61 and 29 individuals caught respectively. In this study, $S$. tranquebarica was absent in Langkawi and Penang, but they are the only species inhibit mangrove areas in Johor and Sabah. Interestingly, no $S$. serrata was collected from the sampling locations. Table 1 provides a summary of species occurrences at each sampling site as illustrated in Figure 1.

All samples were successfully sequenced for the COI region, and no evidence was observed in the final 542 bp alignment to indicate the presence of pseudogenes in the data set. The alignment had 77 variable sites with 50 parsimoniously informative sites (Table 2). No insertions, deletions or stop codons were observed among the aligned sequences. Lack of stop codons in the sequences confirmed that the sequences were functional protein coding gene for mitochondrial COI.

Within the four species, intraspecific divergence ranged between 0.3 to $1.0 \%$ while interspecific divergence ranged from $10 \%$ to $21 \%$ with comparatively low divergence between $S$. paramamosain and $S$. tranquebarica and high divergence between $S$. paramamosain and $S$. olivacea (Table 3). The topology generated by MP (Figure 2) and NJ (Figure 3) analysis of COI barcodes showed monophyly of all four species which was strongly supported by bootstrap analysis at all nodes. Above all, the absence of Malaysian $S$. serrata is highlighted. The phylogenetic tree shows that $S$. tranquebarica and $S$. olivacea were more related to each other while $S$. paramamosain formed a sister group to this cluster. Scylla serrata was the most basal among the four species in both trees.

\section{Discussion}

Results of the mtDNA COI gene analysis in the present study have shed light on the genetic makeup of Scylla species, particularly from Malaysia. The high number of parsimonious-informative sites indicates that COI mtDNA is an informative and effective locus candidate for phylogenetic and molecular taxonomy studies (Kamarudin et al. 2011) (Table 2). The phylogenetic analysis of the COI gene confirmed the reciprocally monophyletic status between all Scylla sequences (Figures 2 and 3), thus shows less and/or no geographical association (see Rosly et al. 2013). The monophyly of all species was also well established with a very low intraspecific and high interspecific genetic distances respectively (Table 3). Additionally, the genetic relationships revealed by the maximum parsimony (MP) and neighbor-joining (NJ) trees are in high agreement (four monophyletic clusters) with the same phylogenetic sister-species relatedness with the previous molecular phylogeny study of Scylla, which was also based on COI sequence data (Keenan et al. 1998).

In this study, Scylla olivacea formed the terminal taxon, followed by $S$. tranquebarica, $S$. paramamosain and $S$. serrata which formed the most basal, although the support was not very high (Figures 2 and 3). Despite the fairly wide geographical coverage within the Malaysian waters of Scylla sampling in this study (Figure 1), no genetically identified $S$. serrata was detected. Many previous researchers have reported the abundance of $S$. serrata (see Overton et al. 1997; Keenan et al. 1998; Gopurenko et al. 1999; He et al. 2010; Fratini et al. 2010) in the neighboring waters and it seems unlikely and puzzling that the species does not occur in Malaysia.

Table 1. Number of individuals in each sampling site based on mtDNA COI sequence analysis for three species within genus Scylla from Malaysia.

\begin{tabular}{lccc}
\hline \multicolumn{1}{c}{\begin{tabular}{c} 
Sampling \\
\multicolumn{1}{c}{ sites }
\end{tabular}} & \multicolumn{3}{c}{ Sumber of individuals } \\
\hline Perlis & 9 & S. tranquebarica & S. paramamosain \\
Langkawi, & 15 & 1 & 0 \\
Kedah & & 0 & 1 \\
Penang & 31 & 0 & 7 \\
Perak & 24 & 10 & 10 \\
Kelantan & 5 & 2 & 7 \\
Terengganu & 8 & 4 & 2 \\
Johor & 0 & 10 & 0 \\
Sarawak & 19 & 9 & 2 \\
Sabah & 0 & 25 & 0 \\
Total & 111 & 61 & 29 \\
\hline
\end{tabular}

Table 2. Number of haplotype (Nhap) and number of site (variable, conserved and parsimonious informative sites) for each member within genus Scylla. $N=$ sample size

\begin{tabular}{lccccc}
\hline \multicolumn{1}{c}{ Taxa } & N & Nhap & \multicolumn{3}{c}{$\begin{array}{c}\text { Number of sites } \\
\text { Parsimonious } \\
\text { Variable }\end{array}$} \\
& & & & $\begin{array}{c}\text { Conserved } \\
\text { informative } \\
\text { sites }\end{array}$ \\
\hline S. olivacea & 111 & 66 & 50 & 492 & 35 \\
S. tranquebarica & 61 & 12 & 12 & 530 & 8 \\
S. paramamosain & 29 & 16 & 15 & 527 & 7 \\
S. serrata & 4 & 3 & 2 & 540 & 1 \\
(imported, not & & & & & \\
from sampling site) & & & & & \\
\hline
\end{tabular}

Table 3. Pairwise Tamura-Nei genetic distances $\left(D_{s}\right)$ among and within species of Scylla

\begin{tabular}{llll}
\hline Species & S. olivacea & S. tranquebarica & S. paramamosain \\
\hline S. olivacea & 0.011 & & \\
S. tranquebarica & 0.172 & 0.003 & \\
S. paramamosain & 0.209 & 0.100 & 0.006 \\
\hline
\end{tabular}




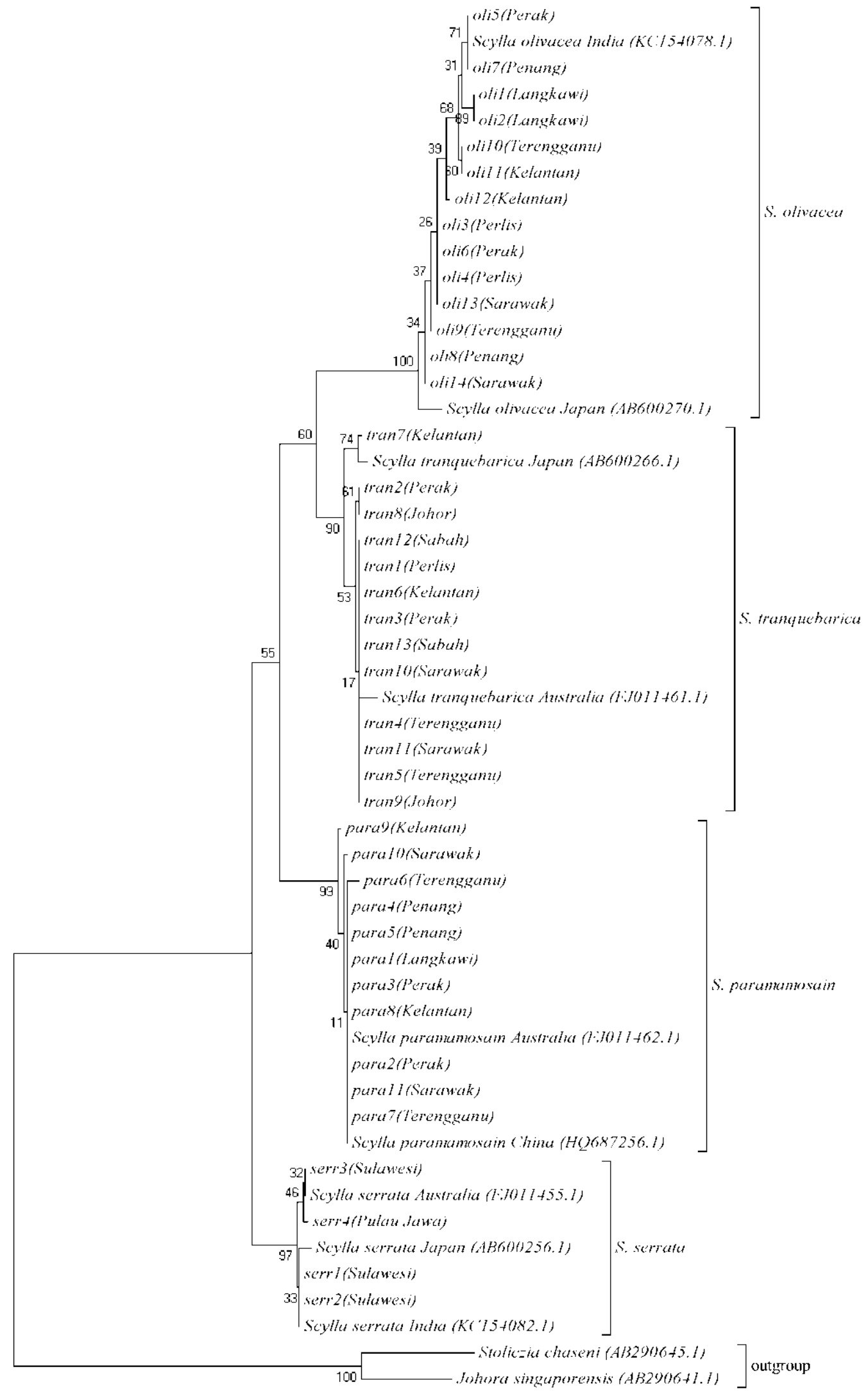

10

Figure 2. Maximum Parsimony (MP) phylogenetic tree showing the relationships among cytochrome c oxidase I (COI) sequences of Scylla with additional sequences from GenBank and sequences of imported S. serrata from Indonesia 


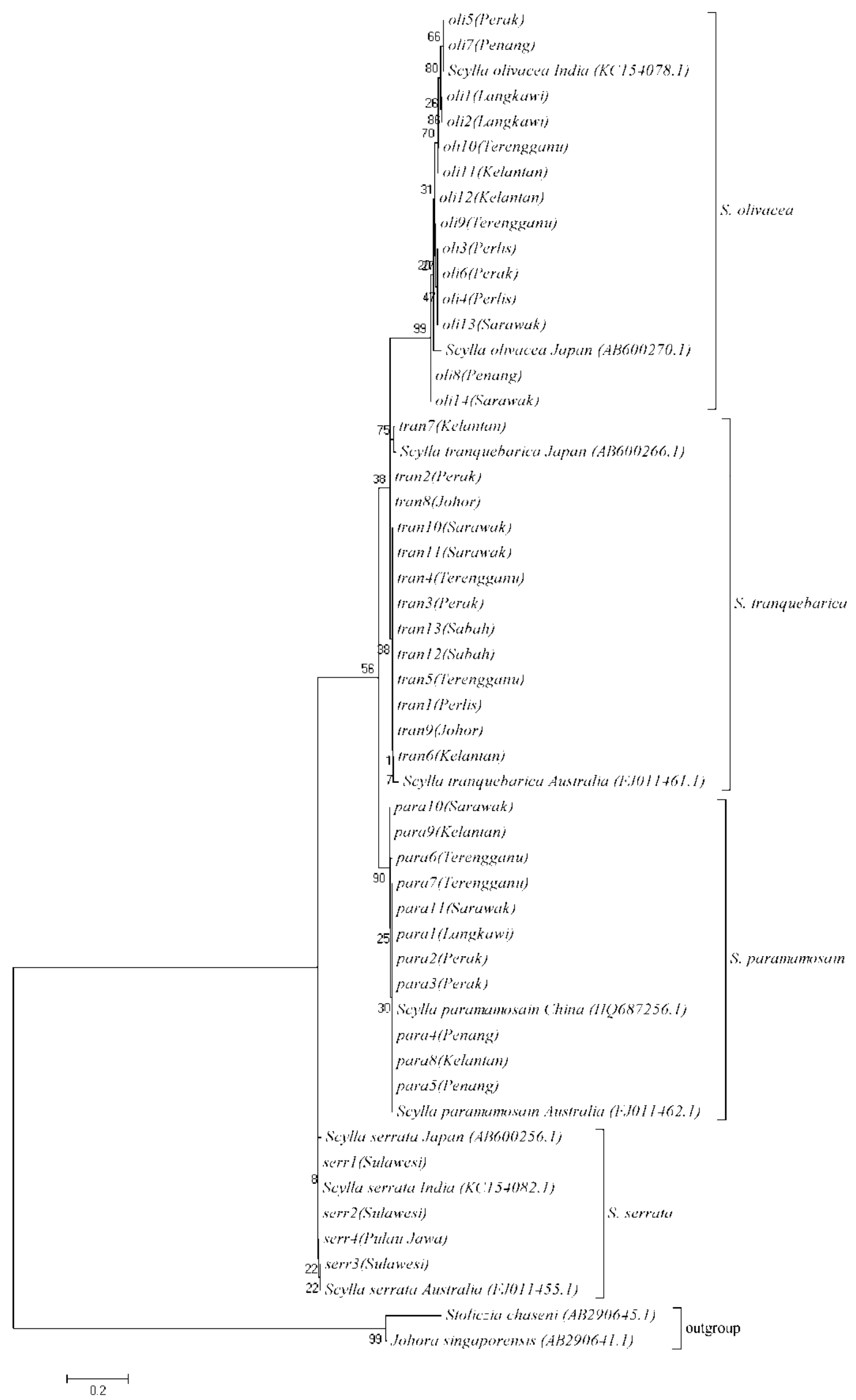

Figure 3. Neighbour-joining (NJ) phylogenetic tree showing the relationships among cytochrome $c$ oxidase I (COI) sequences of Scylla species (with additional sequences from GenBank and sequences of imported $S$. serrata from Indonesia) 
An obvious explanation is overharvesting may have caused such a decline that the limited number of samples and efforts failed to trap any $S$. serrata. But this species is not considered as an endangered group. However, there may be other underlying reasons, which cannot be pinpointed based on present knowledge. A study by Kosuge (2001) reported that out of 81 individuals, more than $60 \%$ of mud crab species sampled from the Matang Mangrove Forest Research off the Straits of Malacca were $S$. serrata while $S$. olivacea made up the remaining samples (no $S$. paramamosain and $S$. tranquebaria were reported). This earlier finding is in wide contrast to this study. However, $80 \%$ of the mud crabs sampled by Kosuge (2001) were immature. This could have led to misidentification.

The area which is close to the original sampling by Kosuge (2001) was resampled to further confirm the existence of $S$. serrata in the location recorded in Kosuge (2001). Accordingly, both types (two groups of morphological variants) of $S$. serrata were obtained in this study (unpublished data). However, COI gene did not identify any of the two groups into S. serrata species. Furthermore, several researchers (Ikhwanudddin 2001; Ikhwanuddin et al. 2010, 2011; Mohammad Zaidi et al. 2011) reported that this species is not found on the continental coast of the South China Sea based on morphological characters, although they are common in the Indo-Pacific Ocean (Keenan et al. 1998). However, these previous Malaysian studies were only focused on the Setiu Wetlands and Sarawak. The Straits of Malacca are an extension of this wide ocean, which is the native habitat of this species.

While several authors have recorded panmixia for this species over a wide geographical range, Gopurenko and Hughes (2002) recorded a strong genetic structure on a meso-geographic scale in Australia. These differences were attributed to the differential influence of abiotic factors acting on the movement and/or on the survival within the different parts of the species distributional range during its pelagic phases. If it is proven by further extensive and intensive sampling, that $S$. serrata is not present in the surrounding of Malaysian waters and possibly slightly beyond, it could be hypothesized that they may be hydrological factors that prevent recruitment into the Malaysian waters. Fratini et al. (2010) did an extensive phylogeographic study of this species in the Indo-West Pacific Ocean (from Africa right to Australia including Southeast Asia) but it is noteworthy to add that no samples within the present area of study were included in their analysis. Similarly, He et al. (2011) analyzed a total of 439 sequences from 24 locations throughout the Indo-West Pacific but no Malaysian samples were included (presumably because no previous molecular study has been conducted in Malaysia). Thus, more sampling efforts and utilization of molecular markers are needed to confirm their presence as reported by Kosuge (2001), or otherwise, in the Straits of Malacca.

On the whole, in this study we were able to provide useful insights into phylogenetic relationships and genetic identity of Scylla species; particularly from Malaysia and surrounding waters. However, further studies using larger samples from other areas of its geographical distribution, sequence data from other mtDNA regions, and information based on nuclear DNA markers are required before any appropriate conservation management strategies for Scylla species are implemented.

\section{ACKNOWLEDGEMENTS}

We thank the Fisheries Research Institute of Penang for their assistance in sample collection, members of the 308 Laboratory, Universiti Sains Malaysia for their full support throughout the project and all of the people involved in sample collection and laboratory work. This project was funded by Universiti Sains Malaysia through research grant 304/PBIOLOGI/6311003, 1001/PBIOLOGY/815087 and 203/PTS/6720007.

\section{REFERENCES}

Abdullah ML, Mohd Nor SA, Naim DM. 2017. Use of DNA barcode in the identification of catfishes (Siluriformes: Ariidae) from Malaysia. Biodiversitas 18 (4): 1358-1366.

Apte S, Smith PJ, Wallis GP. 2007. Mitochondrial phylogeography of New Zealand freshwater crayfishes, Paranephrops spp. Mol Ecol 16: 1897-1908.

Bell JD, Gervis M. 1999. New species for coastal aquaculture in the tropical Pacific-constraints, prospects and considerations. Aqua Int 7: 207-223.

Botello A, Alvarez F. 2010. Genetic variation in the stygobitic shrimp Creaseria morleyi (Decapoda: Palaemonidae), evidence of bottlenecks and re-invasions in the Yucatan Peninsula. Biol J Lin Soc 99: 315-325.

David MHO. 2009. Mud crab (Scylla serrata) culture: understanding the technology in a silvofisheries perspective. Western Indian Ocean J Mar Sci 8: 127-137.

Estampador EP. 1949. Studies on Scylla (Crustacea: Portunidae), I. Revision of the genus. Philippine J Sci 78: 95-109.

Ewel KC. 2008. Mangrove crab (Scylla serrata) populations may sometimes be best managed locally. J Sea Res 59: 114-120.

Farris JS. 1983. The logical basis of phylogenetic analysis. Adv Clad 2: 736.

Francis J, Bryceson I. 2001. Tanzanian coastal and marine resources: some examples illustrating questions of sustainable use. Chapter 4 in Ahmed $\mathrm{J}$ et al. "Lessons learned- case studies in sustainable use" IUCN, Switzerland. pp. 76-102.

Fratini S, Ragionieri L, Cannicci S. 2010. Stock structure and demographic history of the Indo-West Pacific mud crab Scylla serrata. Estuarine, Coastal Shelf Sci 86: 51-61.

Fuseya R, Watanabe S. 1996. Genetic variability in the mud crab genus Scylla (Brachyura: Portunidae). Fish Sci 62: 705-709.

Gauffre B. Estoup A. Bretagnolle V. Cosson JF. 2008. Spatial genetic structure of a small rodent in a heterogeneous landscape. Mol Ecol 17: 4619-4629.

Goodall-Copestake WP, Perez-Espona S, Clark MS, Murphy EJ, Seear PJ., Tarling GA. 2010. Swarms of diversity at the gene coxl in Antarctic krill. Heredity 104: 513-518.

Gopurenko D, Hughes JM, Keenan CP. 1999. Mitochondrial DNA evidence for rapid colonization of the Indo-West Pacific by the mud crab Scylla serrata. Mar Biol 134: 227-233.

Gopurenko D. 2002. Genetic structure within the distribution of the IndoWest Pacific mud crab, Scylla serrata (Forskål, 1775). [Dissertation], Griffith University, UK.

Gopurenko D, Hughes JM. 2002. Regional patterns of genetic structure among Australian populations of the mud crab, Scylla serrata 
(Crustacea: Decapoda): evidence from mitochondrial DNA. Mar Freshwater Res 53: 849-857.

Harris DJ, Crandall KA. 2000. Intragenomic variation within ITS1 and ITS2 of freshwater crayfishes (Decapoda: Cambaridae): implications for phylogenetic and microsatellite studies. Mol Biol Evol 17: 284-291.

He L, Zhang A, Weese D, Zhu C, Jiang C, Qiao Z. 2010. Late Pleistocene population expansion of Scylla paramamosain along the coast of China: A population dynamic response to the Last Interglacial sea level highstand. J Exp Mar Biol Ecol 385: 20-28.

Ikhwanuddin AM, Oakley S. 1999. Culture of mud crab in mangrove areas: The Sarawak experience. Proceedings of The TCE-Project third workshop on "Integrated Management of Mangrove/Coastal Ecosystems for Sustainable Aquaculture Development", 23-25 March 1999, Kuching, Sarawak, Malaysia.

Imtiaz A, Mohd Nor SA, Naim DM. 2017. Review: Progress and potential of DNA barcoding for species identification of fish species. Biodiversitas 18 (4): 1394-1405.

Hubert N, Hanner R, Holm E, Mandrak NE, Taylor E, Burridge M, Watkinson D, Dumont P, Curry A, Bentzen P, Zhang J, April J, Bernatchez L. 2008. Identifying Canadian freshwater fishes through DNA barcodes. PLoS One 3: e2490.

Hurwood DA, Hughes JM, Bunn SE, Cleary C. 2003. Population structure in the freshwater shrimp (Paratya australiensis) inferred from allozymes and mitochondrial DNA. Heredity 90: 64-70.

Ikhwanuddin AM. 2001. The Biology and Fishery of Mud Crab, genus Scylla in East Malaysia. Degree of Master of Science (Aquatic Science) thesis, Universiti Malaysia Sarawak.

Ikhwanuddin M, Bachok Z, Hilmi MG, Azmie G, Zakaria MZ. 2010. Species diversity, carapace width-body weight relationship, size distribution and sex ratio of mud crab, genus Scylla from Setiu Wetlands of Terengganu coastal waters, Malaysia. J Sustainability Sci Manage 5: 97-109.

Imai H, Cheng JH. Hamasaki K, Numachi KI. 2004. Identification of four mud crab species (genus Scylla) using ITS-1 and 16S rDNA markers. Aquat Living Resour 17: 31-34.

Inoue N, Watanabe H, Kojima S, Sekiguchi H. 2007. Population structure of Japanese spiny lobster Panulirus japonicus inferred by nucleotide sequence analysis of mitochondrial COI gene. Fish Sci 73: 550-556.

Jarman SN, Elliott NG, Nicol S, McMinn A. 2002. Genetic differentiation in the Antarctic coastal krill Euphausia crystallorophias. Heredity 88 $280-287$

Joel DR, Raj PJS. 1980. Taxonomic remarks on two species of the genus Scylla de Haan (Portunidae: Brachyura) from Pulicat Lake. J Inland Fish Soc India 12: 39-50.

Jørstad KE, Nævdal G, Karlsen Ø, Torkildsen S, Paulsen OI, Otterå H. 2004. Long-term studies on genetic interaction between wild and ranched cod Gadus morhua by use of a genetic marked strain. J Fish Biol 65: 318-319.

Kalinowski ST. 2002. Evolutionary and statistical properties of three genetic distances. Mol Ecol 11: 1263-1273.

Kamarudin KR, Rehan AM, Hashim R, Usup G, Ahmad HF, Anua MH Idris MY. 2011. Molecular phylogeny of Holothuria (Mertensiothuria) leucospilota (Brandt 1835) as inferred from cytochrome $c$ oxidase I mitochondrial DNA gene sequences. Sains Malays 40: 125-133.

Keenan CP, Mann DL, Lavery S, Davie P. 1995. Genetic relationships, morphological identification and taxonomy of mangrove crabs, genus Scylla, from throughout the Indo-Pacific. ACIAR Project Report, QDPI, Brisbane.

Keenan CP. 1996. Genetic relationships of mud crabs, genus Scylla, throughout the Indo-West Pacific. In: Evans, L. (Ed). Proceedings, Mud Crab Workshop, Broome, 1995. Aquatic Science Research Unit, Curtin University of Technology, Perth, WA, pp 11-23.

Keenan CP. 1999. Aquaculture of the Mud Crab, Genus Scylla - Past, present and future. In: Keenan CP, Blackshaw A. (eds.). Mud Crab aquaculture and biology. Proceedings of an international scientific forum held in Darwin, Australia (21-24 April 1997). ACIAR Proceedings No. 78, Ferguson and Co., Brisbane, Australia, pp 9-13.

Keenan CP, Davie PJF, Mann DL. 1998. A revision of the genus Scylla de Haan, 1833 (Crustacea: Decapoda: Brachyura: Portunidae). Raffles Bull Zool 46: 217-246.

Kosuge T. 2001. Brief assessment of stock of mud crabs Scylla spp. in Matang Mangrove Forest, Malaysia and proposal for resources management. Japan Agric ResQuart 35: 145-148.
Lawlor JL, Hutchings JA. 2004. Consequences to fitness-related traits of hybridization between farmed and wild Atlantic salmon, Salmo salar. J Fish Biol 65: 319-319.

Le Vay L. 2001. Ecology and management of mud crab Scylla spp. Asian Fish Sci 14: 101-111.

Mahika C, Mhitu H, Kuboja B. 2005. Rapid assessment of abundace and biomass of the mangrove crab (Scylla serrata) and its mariculture development on the Tanga coast. Report prepared for ACDI/VOCA Tanzania's Smallholder Empowerment \& Economic Growth through Agribusiness \& Association Development (SEEGAAD) Project, Tanga, Tanzania.

Mohammad Zaidi Z, Hilmi MG, Ikhwanuddin M, Bachok Z. 2011. Population Dynamics of Mud Crab, Scylla olivacea from Setiu Wetland Areas, Terengganu, Malaysia. Umtas, Terengganu, Malaysia.

Moser S, Macintosh D, Laoprasert S, Tongdee N. 2005. Population ecology of the mud crab Scylla olivacea: a study in the Ranong mangrove ecosystem, Thailand, with emphasis on juvenile recruitment and mortality. Fish Res 71: 27-41.

Nei M. 1972. Genetic distance between populations. Am Nat 106: 283292.

Nei M. 1978. Estimation of average heterozygosity and genetic distance from a small number of individuals. Genet 89: 583-590.

Nei M, Kumar S. 2000. Molecular Evolution and Phylogenetics. Oxford University Press, Oxford.

Ng PK, Guinot D, Davie PJ. 2008. Systema Brachyurorum: Part I. An annotated checklist of extant brachyuran crabs of the world. Raffles Bull Zool 17: 13-153.

Overton JL, Macintosh DJ, Thorpe RS. 1997. Multivariate analysis of the mud crab Scylla serrata (Brachyura: Portunidae) from four locations in Southeast Asia. Mar Biol 128: 55-62.

Perrier C, Guyomard R, Bagliniere JL, Nikolic N, Evanno G. 2013. Changes in the genetic structure of Atlantic salmon populations over four decades reveal substantial impacts of stocking and potential resiliency. Ecol Evol 3: 2334-2349.

Roehrdanz RL. 1993. An improved primer for PCR amplification of mitochondrial amplification in a variety of insect species. Insect Mol Biol 2: 89-91.

Rosly HAA, M, Nor SAM, Yahya K, Naim DM. 2013. Mitochondrial DNA diversity of mud crab Scylla olivacea(Portunidae) in Peninsular Malaysia: a preliminary assessment. Mol Biol Rep 40: 6407-6418

Sara L, Ingles JA, Baldevarona RB, Aguilar RO, Laureta LV, Watanabe S. 2002. Reproductive biology of mud crab Scylla serrata in Lawele Bay, Southeast Sulawesi, Indonesia. Crustacean Fish 2002: 88-95.

Sara L. 2010. Study on the size structure and population parameters of mud crab Scylla serrata in Lawele Bay, Southeast Sulawesi, Indonesia. J Coastal Dev 13: 133-147.

Shelley C. 2008. Capture-based aquaculture of mud crabs (Scylla spp.). In Lovatelli A, Holthus PF (eds). Capture-based aquaculture. Global overview. FAO Fisheries Technical Paper 508. FAO, Rome.

Shelley C, Lovatelli A. 2011. Mud crab aquaculture: a practical manual. FAO Fisheries and Aquaculture Technical Paper 567. FAO, Rome.

Stamatis C, Triantafyllidis A, Moutou A, Mamuris Z. 2004. Mitochondrial DNA variation in Northeast Atlantic and Mediterranean populations of Norway lobster, Nephrops norvegicus. Mol Ecol 13: 1377-1390.

Tamura K. 1992. Estimation of the number of nucleotide substitutions when there are strong transition-transversion and $\mathrm{G}+\mathrm{C}$ content biases. Mol Biol Evol 9: 678-687.

Tamura K, Nei M. 1993. Estimation of the number of nucleotide substitutions in the control region of mitochondrial DNA in humans and chimpanzees. Mol Biol Evol 10: 512-526.

Tamura K, Peterson D, Peterson N, Stecher G, Nei M, Kumar S. 2011. MEGA5: molecular evolutionary genetics analysis using maximum likelihood, evolutionary distance, and maximum parsimony methods. Mol Biol Evol 28: 2731-2739.

Utter F. 2004. Population genetics, conservation and evolution in salmonids and other widely cultured fishes: some perspectives over six decades. J Fish Biol 65: 323-324.

Ward RD, Zemlak TS, Innes BH, Last PR, Hebert PD. 2005. DNA barcoding Australia's fish species. Phil Trans R Soc B: Biol Sci 360: 1847-1857.

Williams MJ, Primavera JH. 2001. Choosing tropical portunid species for culture, domestication and stock enhancement in the Indo-Pacific. Asian Fish Sci 14: 121-142 
Wong SL. 2004. Matang Mangroves: A Century of Sustainable Management. Sasyaz Holdings Private Ltd., Petaling Jaya.

Xu XJ, Wang GZ, Wang KJ, Li SJ. 2009. Isolation and characterization of ten new polymorphic microsatellite loci in the mud crab Scylla paramamosain. Conserv Genet 10:1877-1878.
Yalin S, Qingsheng L. 1994. Present status of mangrove crab Scylla serrata (Forskål) culture in China. Naga ICLARM Q 17: 28-29. 